\title{
Ipteks bagi Masyarakat Desa/Kelurahan Tangguh Bencana Melalui Kelompok Siaga Bencana Kelurahan Air Manis, Kecamatan Padang Selatan, Kota Padang, Sumatera Barat
}

\author{
Ansosry \\ Teknik Pertambangan, Fakultas Teknik Universitas Negeri Padang \\ email: ${ }^{1}$ ansosry@yahoo.co.id
}

\begin{abstract}
ABSTRAK
Program kegiatan ini lebih bersifat komprehensif, bermakna, tuntas dan dapat menjadi problem solving dalam mencapai sasaran serta harapan masyarakat terkait penanggulangan bencana. Kegiatan ini selaras dengan tujuan program pengabdian dengan lebih melibatkan kelompok masyarakat dalam membantu menciptakan kenyamanan serta meningkatkan kesiapsiagaan terhadap bencana. Dalam kegiatan ini nantinya akan memberdayakan kelompok siaga bencana (KSB). Sebagai langkah awal telah dilakukan studi literatur dan identifikasi permasalahan yang dihadapi mitra. Selanjutnya dilaksanakan surve geologis daerah. Berdasarkan kondisi kelurahan Air Manis, tim pengabdian mencoba menyusun alat bantú análisis untuk penilaian ketangguhan desa tersebut. Tim pengabdian melakukan analisa pembobotan berdasarkan indikator dan parameter yang telah ditentukan dalam aturan kepala BNPB. Kegiatan sosialisasi program Ibm Desa Tangguh Bencana di Kelurahan Air Manis dilakukan menyesuaikan dengan waktu aktifitas masyarakat. Analisa menghasilkan jenis bencana yang disepakati oleh masyarakat di kelurahan air manis, dari jenis tersebut juga telah teridentifikasi jenis kejadian yang pernah terjadi dan lainnya merupakan potensi karena belum pernah terjadi, penentuan jumlah kerentanan berupa penduduk terpapar, dampak kerusakan fisik dan bangunan serta lingkungan. Tingkat kapasitas, análisis dilakukan berdasarkan penilaian kuesioner dari tools kesiapsiagaan masyarakat dan tools ketangguhan desa. Analisa dirangkum dalam sebuah matriks tingkat risiko untuk setiap jenis bencana yang ada.
\end{abstract}

Kata Kunci : tools kesiapsiagaan masyarakat, tools ketangguhan desa/kelurahan

\section{PENDAHULUAN}

Hampir seluruh dataran (ketinggian 025 mdpl) dengan luas hampir $22 \%$ dari total luas Kota Padang, merupakan daerah terbangun (build-up area). Di bagian Selatan, khusus di Kecamatan Bungus teluk kabung, umumnya masih merupakan daerah pertanian. Sedangkan di bagian Timur di Air manis, Kec Padang Selatan dominasi oleh kawasan yang berada pada daerah perbukitan dengan kemiringan yang cukup curam dan sebagian lagi area pantai. Dari kondisi wilayah ini, Kelurahan Air Manis memiliki potensi bahaya yang cukup besar diantaranya bahaya erosi, tanah longsor, gempa bumi, tsunami, dll. Ancaman bahaya ini jika tidak segera diantisipasi maka akan dapat menjadi bencana yang menimbulkan kerugian jiwa dan harta benda.

Pengkajian risiko bencana di kelurahan merupakan langkah dasar dalam menyusun perencanaan terkait penanggulangan bencana. Untuk tingkat kelurahan, hal ini dilakukan demi terwujudnya desa/kelurahan tangguh bencana. Aturan yang melandasinya merujuk kepada Peraturan Kepala Badan Nasional Penanggulangan Bencana Nomor 1 tahun 2012 Tentang Desa Tangguh Bencana. Desa/Kelurahan Tangguh 
Bencana merupakan salah satu perwujudan dari tanggung jawab pemerintah untuk memberikan perlindungan kepada masyarakat dari ancaman bencana. Program ini juga sejalan dengan strategistrategi yang menjadi prioritas dalam Rencana Nasional Penanggulangan Bencana (Renas PB) 2010-2014 antara lain: penanggulangan bencana berbasis masyarakat; peningkatan peran LSM dan organisasi masyarakat. Dari kondisi wilayah ini, Kelurahan Air Manis memiliki potensi bahaya yang cukup besar diantaranya bahaya erosi, tanah longsor, gempa bumi dan tsunami. Ancaman bahaya ini jika tidak segera diantisipasi maka akan dapat menjadi bencana yang menimbulkan kerugian jiwa dan harta benda.

Pemerintah Kota Padang dan lembaga sosial masyarakat telah mulai mencoba melakukan beberapa upaya pengurangan risiko bencana di Kelurahan Air Manis. Namun upaya yang dilakukan belum bersifat komprehensif dan berlandaskan aturan yang berlaku di nasional. Hal ini dapat mengakibatkan tumpang tindih dalam perencanaan daerah terkait dengan penanggulangan bencana. untuk mencegah agar hal tersebut tidak terjadi maka perlu dilakukan analisa dasar kajian risiko bencana di tingkat kelurahan.

\section{METODE PELAKSANAAN}

\subsection{Metoda Pendekatan}

Pendekatan dan pendampingan langsung kepada masyarakat secara partisipatif merupakan metode untuk penyelesaian persoalan selama pelaksanaan program. Langkah awal selain survey lapangan, dilaksanakan sekaligus penjaringan komitmen dengan pemerintahan, pemuka nagari dan pihak pihak lain yang akan terlibat selama pelaksanaan program.

Data yang didapatkan dianalisis melalui perhitungan indeks dan akan mendapatkaan tingkat ancaman, ringkat kerentanan, tingkat kapasitas dan tingkat risiko bencana serta diterjemahkan kedalam pemetaan.

Untuk melakukan pengkajian risiko bencana tingkat kelurahan untuk mewujudkan desa/kelurahan tangguh bencana yang akan dikembangkan oleh tim pengabdian menuntut peranan masyarakat yang terlibat dalam program. Masyarakat yang mengetahui kondisi wilayahnya, akan memberikan data serta mencek data terbaru yang berkaitan dan menyepakati bersama rencana kebijakan kelurahan dengan mensinkronkan kegiatan yang telah dilakukan. Sedangkan tim pengabdian akan berperan dalam melakukan analisis kajian risiko yang akan menghasilan tingkat dan peta risiko untuk kelurahan, untuk memastikan kondisi secara ilmu pengetahuan bencana dan merekomendasikan rencana kebijakan yang dapat lakukan kepada "Mitra/KSB Camar Laut I dan Camar Laut II".

\subsection{Rencana Kegiatan}

Rencana kegiatan dalam penyelesaian masalah yang dihadapi KSB Camar Laut I dan Cemar Laut II adalah langkah awal memberikan penyuluhan menjelaskan selengkap mungkin masalah teknis terkait dengan kondisi geologi dan geografis wilayah secara keilmuan. Setelah Kelompok ini memahami dengan benar masalahnya selanjutnya tim pengabdian menjelaskan tahapan-tahapan pelaksanaan metode pengkajian risiko bencana dan melakukan analisis sehingga didapatkan rekomendasi kepada masyarakat.

Tahapan analisa tingkat ancaman, tingkat kerentanan, tingkat kapasitas dan tingkat risiko dalam pengkajian akan dilakukan tim pengabdian jika semua data yang didapatkan dari masyarakat telah tercapai. Hasil analisa tingkat nantinya juga akan di kembangkan dalam pemetaan berdasarkan indeks yang telah didapatkan. Tahap selanjutnya adalah pendampingan oleh tim pengabdian serta penyepakatan secara bersama dan partisipatif masyarakat tentang hasil awal dari analisis kajian 
risiko. Pada tahapan ini juga akan dilakukan penilaian tingkat kapasitas dari masyarakat sehingga dapat diberikan rekomendasi kebijakan untuk kelurahan nantinya. Setelah kedua tahap di atas dilaksanakan dengan baik, tahap berikutnya adalah tahap finalisasi dalam bentuk dokumen kajian serta pemetaan tingkat risiko.

\section{HASIL DAN PEMBAHASAN}

Adapun tujuan dari pembentukan desa/kelurahan tangguh bencana antara lain:

1. Melindungi masyarakat yang tinggal di kawasan rawan bahaya dari dampak dampak merugikan bencana.

2. Meningkatkan peran serta masyarakat, khususnya kelompok rentan, dalam pengelolaan sumber daya dalam rangka mengurangi risiko bencana.

3. Meningkatkan kapasitas kelembagaan masyarakat dalam pengelolaan sumber daya dan pemeliharaan kearifan lokal bagi pengurangan risiko bencana.

4. Meningkatkan kapasitas pemerintah dalam memberikan dukungan sumber daya dan teknis bagi pengurangan risiko bencana.

5. Meningkatkan kerjasama antara para pemangku kepentingan dalam PRB, pihak pemerinta daerah, sektor swasta, perguruan tinggi, LSM, organisasi masyarakat dan kelompok-kelompok lainnya yang peduli.

Terkait dengan pengurangan risiko bencana di Kelurahan Air Manis, beberapa metode dapat dilakukan secara pertisipatif dengan masyarakat. Salah satu inisiatif yang dapat dilakukan dalam pembentukan desa/kelurahan tangguh bencana dengan menyusun pemetaan dan kajian risiko bencana Kelurahan. Upaya ini dilakukan secara partisipatif dengan melibatkan kelompok siaga bencana di Kelurahan Air
Manis. Metode ini ditunjang dengan alat bantú penilaian ketangguhan desa yang dikembangkan oleh tim pengabdian.

\subsection{Survey identifikasi permasalahan}

Untuk mengetahui dasar permasalahan yang akan dijadikan intervensi oleh tim pengabdian maka dilakukan kunjungan awal ke Kelurahan Air Manis. Kunjungan langsung melihat kondisi Kelurahan Air Manis dilakukan untuk mengetahui perkembangan kegiatan yang dilakukan masyarakat terkait pengurangan risiko bencana. Kegiatan pengurangan risiko bencana yang dilakukan masyarakat selama ini masih belum menyeluruh dan mendasar. Intervensi yang dilakukan kepada masyarakat dengan membentuk kelompok siaga bencana tidak dilandasi dengan dasar analisa yang jelas. Beberapa pelatihan penanggulangan bencana dan kegiatan lain telah dilakukan namun belum ada sebuah alat bantú ataupun perangkat penilaian untuk mengetahui kondisi ketangguhan Kelurahan Air Manis terhadap bencana.

Tim pengabdian mengamati dari kunjungan lapangan yang dilakukan, perlu adanya mengetahui dasar kajian risiko bencana di Kelurahan Air Manis. Kajian risiko bencana dilakukan untuk mengetahui jenis bahaya, kerentanan, kapasitas dan tingkat risiko untuk setiap jenis bencana yang berpotensi tersebut. Hasil kajian tersebut diperkuat dengan adanya pemetaan wilayah yang terkena dampak bencana secara partisipatif. Hal lain yang dapat dilakukan dengan menilai tingkat ketangguhan Kelurahan Air Manis terhadap potensi bencana yang mengancam.

\subsection{Koordinasi untuk penjaringan komitmen}

Pada saat koordinasi dilakukan pendekatan persuasi dengan pemangku kepentingan dan kebijakan di kecamatan dan kelurahan. Pada saat koordinasi awal didapatkan kesepakatan dan dukungan 
dalam pelaksanaan kegiatan nantinya. Hal ini dikarenakan kegiatan yang dilakukan sangat dibutuhkan oleh masyarakat. Kondisi daerah yang rawan serta kondisi masyarakat yang membutuhkan perhatian terkait upaya pengurangan risiko bencana.

\subsection{Survey awal dan pemetaan wilayah}

Secara geologis, wilayah Kelurahan Air Manis berada pada dasar atau atas lereng perbukitan, berada pada punggungan bukit, dan dibawah bukit yang curam dengan litologi yang bersifat lepas, juga berkembang dengan intensif lokasilokasi yang mengalami deformasi, lokasilokasi ini yang sangat berpotensi terjadi longsoran. Secara geologis, wilayah Kelurahan Air Manis berada pada dasar atau atas lereng perbukitan, berada pada punggungan bukit, dan dibawah bukit yang curam dengan litologi yang bersifat lepas, juga berkembang dengan intensif lokasilokasi yang mengalami deformasi, lokasilokasi ini yang sangat berpotensi terjadi longsoran.

Kondisi geografis Kelurahan Air Manis, Kecamatan Padang Selatan, Kota Padang terdiri dari wilayah dengan morfologi perbukitan dan morfologi dataran pantai (Coastal Plain). Morfologi perbukitan dibangun oleh batuan yang berumur Pra-Tersier (batuan metamorf): filit, batulanau meta, kwarsit dan batugamping meta. Di atas ditutupi secara tidak selaras oleh endapan gunung api Tersier-Kuarter (tufa kristal, ignimbrite, agglomerat, breksi, lahar dan lava andesitik). Batuan yang dominan menempati daerah Air Manis dan sekitarnya adalah tufa dan breksi yang mengalami struktur ketika lapuk mudah mengalami erosi dan longsoran, jatuhan batuan, dan guguran lereng. Morfologi dataran pantai (Coastal Plain) menempati sebagian besar wilayah pengabdian. Morfologi ini dibangun oleh : akumulasi pasir pantai (Coastal Sandbars) dan endapan rawa pantai (Backswamps). Batuan yang menempati dataran pantai yang terdiri-dari endapan pasir lepas ketika terkena gelombang laut dan pantai mudah mengalami erosi dan abrasi .

Daerah bukit Gado-gado, Siti Nurbaya dan sekitarnya yang berpotensi longsoran mempunyai sudut kelerengan yang bervariasi, yaitu kelerengan dengan sudut $\pm 30^{\circ}$ yang terdapat pada daerah tengah sampai kaki bukit dan kelerengan dengan sudut $\pm 35^{\circ}$ - $40^{\circ}$ yang terdapat pada daerah tengah sampai puncak bukit. Daerah tengah bukit yang berpotensi longsoran dengan ketebalan soil mencapai $\pm 20-80 \mathrm{~cm}$. Analisa data tersebut didapatkan dari pemetaan lebih detail dan analisa geolistrik yang terlihat pada gambar 5.

Tataguna lahan di daerah tengah bukit yang berpotensi longsoran berupa semak belukar dan di bagian kaki bukit permukiman. Air yang terus menerus tertahan di tengah bukit akibat adanya retakan-retakan tanah berakibat pada bertambahnya intensitas air yang masuk ke dalam tanah. Kondisi seperti ini akan menurunkan kuat geser tanah secara signifikan dan meningkatkan beban lereng. Morfologi daerah penelitian yang miring menyebabkan gaya vertikal yang menarik batuan ke arah bawah semakin tinggi, hal ini mendukung terjadinya longsoran di daerah pengabdian.

Pantai landai berpasir di Kelurahan Air Manis tersusun oleh endapan pasir halus hingga kasar berwarna kuning kecoklatan hingga keabu-abuan. Sumbernya diduga berasal dari darat (terrigeneous), memiliki komposisi mineral kuarsa, felspar dan plagioklas, sebagian besar mengandung fragmen cangkang moluska. Pantainya memiliki morfologi landai dengan relief rendah hingga menengah, dan memiliki pedataran pantai yang cukup luas. Namun, di beberapa tempat luas pedataran menyempit, karena lahan lebih banyak dimanfaatkan sebagai pemukiman dan sarana umum lainnya. umumnya memiliki garis pantai lurus, dengan kemiringan bibir 
pantai yang landai hingga curam. Proses dinamika pantai yang teramati adalah abrasi. Pemanfaatan lahan antara lain sebagai tempat wisata, tempat tambat perahu nelayan, pemukiman, dan sarana umum lainnya. Jenis vegetasi penutup terdiri atas pohon kelapa, cemara, semak.

\subsection{Penyusunan tools ketangguhan desa}

Dasar dalam penyusunan alat bantú untuk penilaian ketangguhan desa/kelurahan mengacu kepada Peraturan Kepala Badan Nasional Penanggulangan Bencana Nomor 1 Tahun 2012 Tentang Pedoman Desa/Kelurahan Tangguh Bencana. Dalam peraturan tersebut telah dijelaskan beberapa indikator dan parameter pencapaian sebuah desa/kelurahan tangguh bencana. Namun demikian pengolahan indikator dan parameter tersebut belum ada sehingga belum ada penilaian dari analisa indikator tersebut.

Berdasarkan kondisi tersebut, tim pengabdian mencoba menyusun alat bantú análisis untuk penilaian ketangguhan desa/kelurahan tersebut. Proses penyusunan alat bantú ini membutuhkan waktu cukup lama sejak awal mulai program hingga pertengahan program berjalan. Tim pengabdian melakukan analisa pembobotan berdasarkan indikator dan parameter yang telah ditentukan dalam aturan kepala BNPB. Untuk mempermudah mendapatkan hasil analisa maka perlu dilakukan dalam bentuk software/program yang khusus dikembangkan untuk ketangguhan desa/kelurahan ini. Untuk penyempurnaan layout atau tampilan dalam bentuk software ini, tim pengabdian bekerjasama dengan DRR Indonesia consultant.

\subsection{Penyusunan Peta Dasar Wilayah}

Peta dasar wilayah merupakan pemetaan administrasi kelurahan yang dilengkapi dengan legenda peta yang terkait dengan analisa kajian risiko bencana. Penyusunan peta dasar berdasarkan peta administrasi yang didapatkan dari Kelurahan. Peta dasar merupakan peta yang dijadikan acuan lanjutan dalam penentuan potensi bahaya untuk jenis bencana yang disepakati di masyarakat.

Penyusunan peta dibuat secara partisipatif masyarakat agar memudahkan penyusunan dan dapat dimengerti oleh masyarakat. Penyusunan peta dasar tidak mengikuti kaidah pemetaan dikarenakan hanya digunakan untuk melihat dan menggambarkan perkiraan kondisi masyarakat dan fasilitas kritis yang ada di kelurahan.

\subsection{Sosialisasi Program}

Kegiatan sosialisasi Desa/Kelurahan Tangguh Bencana di Kelurahan Air Manis dilakukan menyesuaikan dengan waktu aktifitas masyarakat. Wilayah Air Manis merupakan daerah wisata di Kota Padang sehingga penentuan waktu pelaksanaan dikondisikan dengan aktifitas masyarakat tersebut.

Kegiatan sosialisasi difokuskan kepada pemahaman bersama tentang sebuah desa/kelurahan yang termasuk kategori desa/kelurahan tangguh bencana. Dalam kegiatan ini dijelaskan pemahaman dasar, tujuan dari pembentukan desa/kelurahan tangguh bencana serta indikator sebuah desa/kelurahan tangguh bencana. Selain itu dalam kegiatan ini juga disepakati jenis bencana yang pernah terjadi dan yang berpotensi terjadi di Kelurahan Air Manis.

\subsection{Analisa risiko bencana kelurahan}

Proses lanjutan dari data lapangan dan kesepakatan jenis bencana secara partisipatif di masyarakat adalah analisa kajian risiko bencana. Proses analisa ini dilakukan oleh tim pengabdian berdasarkan data dan peta yang telah disusun sebelumnya. Analisa kajian risiko terkait dengan analisa tingkat bahaya, tingkat kerentanan, tingkat kapasitas dan tingkat risiko bencana. 
Penilaian risiko bencana di tingkat desa/kelurahan merupakan pengembangan dari kajian risiko bencana yang telah ditetapkan oleh BNPB. Oleh sebab itu, untuk tingkat desa/kelurahan, kedalaman análisis mendekati data yang didapatkan dari RW/RT yang ada di desa/kelurahan tersebut.

\section{Hasil :}

1. Telah adanya identifikasi jenis bahaya, dampak kejadian dan luasan daerah yang terkena dampak.

2. Penentuan jumlah kerentanan berupa penduduk terpapar, dampak kerusakan fisik dan bangunan serta lingkungan.

3. Tingkat kapasitas, análisis dilakukan berdasarkan penilaian kuesioner dari tools kesiapsiagaan masyarakat dan tools ketangguhan desa

4. Analisa dirangkum dalam sebuah matriks tingkat risiko untuk setiap jenis bencana yang ada

\section{Kendala :}

Masih kurang lengkapnya data yang dibutuhkan untuk tingkatan RW/RT di kelurahan Air Manis.

\section{Diskusi Publik}

Peserta yang terlibat bukan hanya dari kelurahan air manis, namun mencakup perwakilan dari kelurahan lain yang ada di Kecamatan Padang Selatan. Pemaparan yang disampaikan nantinya terkait dengan hasil kajian risiko serta menghimpun ketangguhan desa melalui tools ketangguhan desa yang telah disusun sebelumnya. Selain itu, dalam pertemuan ini juga dihimpun rencana tindak lanjut masyarakat di Kelurahan Air Manis khususnya dan Kecamatan Padang Selatan pada umumnya.

\section{Hasil :}

1. Telah adanya kesepakatan dan pemahaman masyarakat terkait dengan tingkat bahaya, tingkat kerentanan, tingkat kapasitas dan tingkat risiko untuk seluruh bencana yang berpotensi di Kelurahan Air Manis.

2. Telah didapatkannya hasil penilaian dari tools ketangguhan desa dan kesiapsiagaan masyarakat berupa nilai dan beberapa rekomendasi kebijakan untuk penanggulangan bencana di Kelurahan Air Manis.

3. Adanya kesepakatan bersama tentang rencana tindak lanjut dari masyarakat di Kelurahan Air Manis berdasarkan kajian risiko bencana dan beberapa rekomendasi yang dihasilkan untuk lebih meningkatkan ketangguhan desa dalam menghadapi bencana.

\section{Kendala :}

Waktu pelaksanaan terlalu singkat sehingga beberapa hasil yang didapatkan masih bersifat umum.

\section{Monitoring Dan Evaluasi}

Dalam kegiatan ini, tim monitoring memantau perkembangan dan kemajuan kegiatan dari tim pengabdian yang telah melakukan beberapa kegiatan di masyarakat.

Untuk monitoring dan evaluasi secara tidak langsung dapat dilakukan oleh tim pengabdian dengan berkoordinasi dengan pihak kelurahan dan kecamatan. Evaluasi dapat dilakukan setelah seluruh rangkaian kegiatan telah terlaksana berdasarkan rencana tindak lanjut yang disepakati bersama. Proses ini dapat dilakukan secara berkala dikarenakan lokasi kegiatan tidak jauh dengan universitas tempat tim pengabdian.

\section{Hasil :}

1. Kemajuan kegiatan sudah cukup baik hingga kini tahapan yang dilaksanakan hanya tinggal finalisasi hasil dan capaian.

2. Penggunaan tools ketangguhan desa dan kesiapsiagaan masyarakat merupakan salah satu alat bantu yang 
cukup efektif untuk menilai capaian dan rekomendasi lanjutan terkait upaya untuk membangun sebuah desa tangguh bencana

3. Adanya rekomendasi tindak lanjut yang dapat dijadikan bahan evaluasi secara berkala sehingga proses lanjutan dapat dipantau.

\section{Kendala :}

Jangka waktu pelaksanaan secara keseluruhan yang sangat terbatas membuat masyarakat merasa perlu adanya keberlanjutan program sehingga dapat memberikan dampak yang lebih dapat dirasakan oleh masyarakat.

\section{KESIMPULAN DAN SARAN}

Pelaksanaan kegiatan pembentukan desa tangguh bencana di Kelurahan air manis telah dilaksanakan oleh tim pengabdian. Berbagai masukan dan kendala yang dihadapi telah dirangkum dan dijelaskan sebelumnya. Masukan dari masyarakat terkait kondisi daerah dan penentuan lokasi dan area yang terkena dampak sangat menentukan hasil analisa kajian risiko bencana. Hal ini dikarenakan metode yang digunakan lebih bersifat partisipatif dan dengan pendekatan langsung ke daerah,

Dari beberapa rangkaian kegiatan yang telah dilakukan, dapat diambil beberapa kesimpulan diantaranya:

1. Teridentifikasi 10 jenis bencana baik yang pernah terjadi maupun yang belum pernah terjadi namun berpotensi terjadi di Kelurahan Air Manis

2. Telah adanya peta dasar kelurahan yang disusun secara partisipatif sebagai acuan dalam menentukan luas bahaya terpapar dari jenis bencana yang telah disepakati bersama.

3. Telah adanya tingkat risiko untuk seluruh jenis bencana sebagai hasil dasar dalam kajian risiko bencana di Kelurahan Air Manis.

4. Telah dilakukan ujicoba penggunaan alat bantu dalam melihat tingkat kesiapsiagaan masyarakat dan nilai level ketangguhan kelurahan Air Manis.

Berdasarkan beberapa hasil yang telah dicapai tersebut maka terdapat beberapa saran dan masukan kedepan yang dapat dijadikan rekomendasi lanjutan diantaranya:

1. Perlu adanya keberlanjutan kegiatan karena hasil ketangguhan desa yang diidentifikasi masih dalam level awal (pratama)

2. Perlu adanya kerjasama berbagai pihak dalam membangun Kelurahan Air Manis menjadi salah satu desa/kelurahan tangguh bencana di Indonesia.

\section{DAFTAR PUSTAKA}

Badan Pusat Statistik, 2001, Sumatera Barat Dalam Angka, BPS Propinsi Sumatera Barat, Padang.

Badan Nasional Penanggulangan Bencana, 2012, Peraturan Kepala Badan Nasional Penanggulangan Bencana nomor 1 tahun 2012 tentang desa tangguh bencana, Jakarta.

Badan Nasional Penanggulangan Bencana, 2012, Peraturan Kepala Badan Nasional Penanggulangan Bencana nomor 2 tahun 2012 tentang pedoman umum pengkajian risiko bencana,, Jakarta.

Direktorat Penelitian Dan Pengabdian Kepada Masyarakat Direktorat Jenderal Pendidikan Tinggi

Kementerian Pendidikan Dan Kebudayaan, 2013 Panduan Pelaksanaan Penelitian Dan Pengabdian Kepada Masyarakat Di Perguruan Tinggi Edisi IX, Jakarta

Kurniawan, Budi 2011, laporan akhir program AIR SUMBAR, MERCYCORPS - Padang 
Kastowo dan Leo. 1973, Peta Geologi Lembar Padang, Sumatera, Skala 1:250.000. Direktorat Geologi, Ditjen Pertambangan Umum. Departemen Pertambangan

Lembaga Pengabdian kepada Masyarakat Universitas Negeri Padang Tahun 2012, Laporan Akuntabilitas Kinerja Instansi Pemerintah (LAKIP), Padang

Lassa, Jonatan, dkk, 2009:"Kiat Tepat Mengurangi Risiko Bencana : Pengelolaan Risiko Bencana Berbasis Komunitas (PRBBK)", Grasindo, Jakarta.

Nakamura, H., 1996, Landslide in Japan, The Landslide Society National Conference of Landslide Control, The Fifth revision, Japan.

Setianingtyas, Lusiana Lilies, dkk., 2008, "Membangun Kekuatan Kolektif Reduksi Resiko Bencana", Wahana Lingkungan Hidup Indonesia, Jakarta.

Standar Nasional Indonesia (SNI 03-17262002), Tentang Tata Cara Perencanaan Ketahanan Gempa untuk Bangunan Gedung, Badan Standarisasi Nasional, Jakarta.

SC-DRR, Rancangan Panduan Desa Tangguh, 2009.

Teuku Mukhlis, dkk 2008, Perencanaan Sistem Peringatan Dini Bencana Tanah Longsor Di Dusun Lucu Palongan Desa Campoan Kecamatan Mlandingan, Kabupaten Situbondo, Jawa Timur.

UN-ISDR, Living with Risk: A Global Review of Disaster Rreduction Initiatives, Geneva: 2004.

Undang-Undang Dasar Negara Republik Indonesia Tahun 1945;
Undang-Undang Nomor 28 Tahun 1999 Tentang Penyelenggaraan Negara Yang Bersih Dan Bebas Dari Korupsi; Kolusi Dan Nepotisme;

Undang-Undang Nomor 39 Tahun 1999 Tentang Hak Asasi Manusia;

Undang-Undang Nomor 25 Tahun 2004 Tentang Sistem Perencanaan Pembangunan Nasional;

Undang-Undang Nomor 32 Tahun 2004 Tentang Pemerintahan Daerah;

Peraturan Kepala Badan Nasional Penanggulangan Bencana Nomor 4 Tahun 2008. Tentang Pedoman Penyusunan Rencana Penanggulangan Bencana;

Paripurno, Eko Teguh, 2006: "Penerapan PRA dalam Penanggulangan Bencana", PSMB UPN Veteran Yogyakarta

Winchester, Simon, 2002: "Krakatau: Ketika Dunia Meledak, 27 Agustus 1883”, Serambi, Jakarta.

Gustavo Wilches and Inter Works, Bencana dan Lingkungan: Program Pelatihan Manajemen Bencana (DMTP), Edisi ke 2, UNDP 1995. 